Arab Univ. J. Agric. Sci., Ain Shams Univ., Cairo, Egypt

27(4), 2247-2257, 2019

Website: http://ajs.journals.ekb.eg

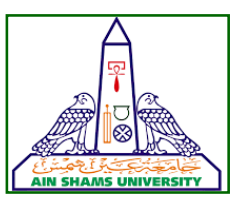

2247

\title{
SEED PRIMING EFFECT ON GERMINATION OF DOUM PALM (Hyphaene thebaica Mart) AND DEVELOPMENT OF SMALL SEEDLING
}

\author{
Negm $^{1^{*}}$ A.H.A., Sohair E. Hassan ${ }^{2}$ and Hewidy ${ }^{2}$ M. \\ 1- Arid Land Agric. Graduate Studies \& Research Institute (ALARI), Ain Shams Univ., Cairo, \\ Egypt \\ 2- Horticulture Dept., Fac. of Agric., Ain Shams Univ., P.O. Box 68, Hadayek Shoubra, 11241 \\ Cairo, Egypt \\ *Corresponding author: negm.a.h@agr.asu.edu.eg
}

Received 29 August, 2019

Accepted 12 November, 2019

\section{ABSTRACT}

Doum palm Hyphaene thebaica Mart is a very important natural flora in the Egyptian territory. It is integrated in food, drink and medicine of the Egyptian population. Seeds germination faces difficulties due to hardness and viability. The fruit (a date) is edible, the foliage is also used for local crafts, the stems for construction purposes, and the roots for phytomedicine, mainly for the treatment of bilharziasis. This study tried different priming methods after removal hard kernel. First treatment; nontreated as direct plantation (control). Second; Cold water (tap water for 48 hours), third; freezing storage in Deep-freezer at $-18^{\circ} \mathrm{C}$ for 12 hours then immersed in $60^{\circ} \mathrm{C}$ water for 1 hour, fourth; hot water at $60^{\circ} \mathrm{C} \pm 5$ for 3 hours then left till gradually cooled, fifth; soaking seeds in a solution of gibberellic acid 200 ppm for 48 hours, sixth; Soaking seeds in $3 \%$ solution of $\mathrm{KNO}_{3}$ for 48 hours, seventh; soaking seeds in diluted sulfuric acid $\left(\mathrm{H}_{2} \mathrm{SO}_{4}\right)$ at $30 \%$ for 15 minutes. Data collected were germination percentage $\%$, roots length, root diameter, root fresh and dry weight, root dry weight, seedling length, wide of leaf, Fresh and dry weight of above ground parts. Freezing followed by hot water gave the highest seed germination $\%(90 \%)$ followed by $\mathrm{KNO}_{3}(80 \%)$. The lowest germination \% was obtained from non-treated control and cold water in a range between $45-65 \%$. Cold water treatment gave significant increase in root fresh weight in both seasons when compared to other treatment. Freezing and cold water treatment gave significant increase in plant height in both seasons when compared to other treatments. Moreover, the effect of various priming treatment demonstrated significant effect on characteristics of young growing
\end{abstract}

seedling. The best performance obtained from seeds treated with cold water and freezing treatment. Thus, treating Doum palm seeds after removal of hard kernel with freezing at -18 for 12 hours followed by immersing seed in hot water at $60^{\circ} \mathrm{C}$ for one hour.

Keywords: Seed priming, Hyphaene thebaica, Seedling, $\mathrm{KNO}_{3}, \mathrm{GA}_{3}$, Freezing.

\section{INTRODUCTION}

Dormancy of seed due to inhibitory factors, are either due to hard seed coat (external) or physical of physiological status of interior of the seed. Seed dormancy in Doum palm ( $H$. thebaica Mart) belongs to the first type. Some trees that produces seeds with hard seed coat such as Doum which is common component of flora of the southern of Egypt and other arid region are restricted in the distribution in the region because of the prolong dormancy and poor germination rate. The dormancy breaking treatment overcome the dormancy of this plant (Al-Fredan and Ali, 2008).

Zevallos and De La Cruz (1991) reported that, the seed germination rates were increased in Acacia marcracantha and cyathostegia mathewsii by soaking in cold water for $28 \mathrm{~h}$. In contrast, Chris (1994) reported that soaking in cold water not appreciably increase level of germination for some Acacia species. Kasera et al (2002) were subjected seeds to tap water for $24 \mathrm{~h}$ in Leptadaenia reticulate plant and were found that, the highest germination percentage $100 \%$ obtained with this treatment. Also, Çırak et al (2007) clarified that, the soaked seeds in tap water of Hypericum aviculaviifolium resulted in better seed germination percentage. 
Chris (1994) reported that, hot water treatment for some Acacia species did not appreciably increase germination level as well as the duration of water soaking treatments. Cervantes et al (1996) found that, seed germination of leucaena exculenta and L. macrophylla occurred after soaking in boiling hot water for $1 \mathrm{~min}$. Mechanical Scarification for seed coat can be done by scratch the seed coat by agrail, knife or shaking seeds with some abrasive materials.

Smith (1979) reported that, mechanical seed scarification improved the germination rate of $\mathrm{Za}$ mia integrifolia and Z. furfuracea. Also, the same results were found for scarified feeds of Albizzia elurozz when compared to non-scarified ones (Gogue and Emino, 1980). Similarly, Scarified seeds of koelreuteria paniculata gave the best result of germination (91.0\%) (Garner and Lewis 1980). Gupta et al (2001) subjected seeds of $\mathrm{Abu}$ tilon indicum to different hot water treatments and found that, the highest germination percentage $(82 \%)$ occurred with $70^{\circ} \mathrm{C}$ hot water treatment.

Witte (1977) clarified that, seeds of Zamia plants were collected in 1976 and cleaned, then either germinate or stored one year at $5^{\circ} \mathrm{C}$. With fresh seed planted in $30^{\circ} \mathrm{C}$ media, germination was about equal for cracked and uncracked seed (60 to $65 \%$ ), but only $43 \%$ for shelled seed. After storage, cracked seed germination better than uncracked (71\% vs. $38 \%$ ) and mild bottom heat increased germination of uncracked seed ( $49 \%$ vs. $27 \%$ ) but not cracked seed. Heavier seed $(29 \mathrm{~g})$ germinated better than lighter one $(1.69 \mathrm{~g})$.

Tilki and Dirik (2007) studied the effect of cold stratification for 0 or 45 days at $4 \pm 1^{\circ} \mathrm{C}$ in three provenances of Pinus brutia and found that, stratification significantly increased germination $\%$ at all potentials under study regardless germination temperature.

Thus, we conducted this research to conduct effect of seed priming on germination of Doum palm (Hyphaene thebaica) seeds and growing young seedling.

\section{MATERIAL AND METHODS}

\section{Plant Material}

Seeds of Hyphaene thebaica plants (Doum Palm) were bought from El Obour Market as a source of plant material during two seasons of the study. The average fresh weight of the seeds were about $18 \mathrm{~g}$ and $10 \mathrm{~cm}$ in diameter.

\section{Media used \& preparation}

The culture media used were 1:1 sand: peatmoss (v/v). Sand was washed by water and mixed with peatmoss then treated with $1 \mathrm{~g} / \mathrm{l}$ Rizolex as disinfectant for soil spores, then media were mixed with calcium nitrate to adapt $\mathrm{pH}$ of the soil. Plastic bags used were about $(18 \times 25 \mathrm{~cm})$ in diameter as a container filled with the above mentioned medium.

\section{Seed treatments}

Seeds of Doum Palm were treated after removal of the hard kernel with different priming treatments as follows:

1. Control treatment without soaking. (Direct plantation).

2. Soaking in tap water for 48 hours (cold water).

3. Freezing storage in Deep-freezer at $-18^{\circ} \mathrm{C}$ for 12 hours then soaked in Hot water at $60^{\circ} \mathrm{C}$ for 1 hour.

4. Soaking in Hot water $\left(60^{\circ} \mathrm{C} \pm 5\right)$ for 3 hours then left till gradually cooled.

5. Soaking in a solution of gibberellic acid $\left(\mathrm{GA}_{3}\right)$ 200 ppm for 48 hours.

6. Soaking in a solution of potassium nitrate $\left(\mathrm{KNO}_{3}\right) 3 \%$ for 48 hours.

7. Soaking in sulfuric acid $\left(\mathrm{H}_{2} \mathrm{SO}_{4}\right) 30 \%$ for 15 minutes.

\section{Sowing date $\&$ farming procedure}

The sowing date was in 12 April for the two seasons under study (2017/2018). All treatments were cultured in the plastic bags about $3 \mathrm{~cm}$ in depth under the surface of media then coated with sand. All treatments were then shaded with serran sheets and irrigated immediately after sowing. Irrigation of all treatments was performed every week by tap water.

\section{Data Recorded \& Statistical analysis}

The data were recorded in October of both seasons as follow.

1 - Germination percentage $\%=$ $\frac{\text { Number of germentaed seeds }}{\text { total number of seeds }} \times 100 \%$

2- Length of roots.

3- Root diameter diameter.

4- Root fresh weight.

5- Root dry weight. 
6- Length of seeding.

7- Wide of leaf.

8- Fresh weight of above ground parts.

9- Dry weight of above ground parts.

Collected data were subjected to one-way analysis of variance was carried out, as described by Snedecor and Cochran (1989). The means were compared by determining for the germination experiment. Each treatment of the seed presoaking experiments consisted of 3 replicates and 5 seeds in each replicate. Duncan test $(P \leq 0)$ was used for analysis of the data, to evaluate differences among means (Waller and Duncan, 1969).

\section{RESULTS}

\section{Germination percentage}

Data presented in Fig. (1) indicate that seed germination percentage of $H$. thebaica was significantly affected by different treatments. The highest germination \% was obtained from seeds treated with Freezing treatment (86.66 and 90\%) and followed by soaked seeds in $\mathrm{KNO}_{3}$ ( 80 and $76 \%$ ) in respect order by season. Meanwhile, the lowest germination \% was observed when seeds were not treated with any priming methods as control (46.66 and $50 \%)$.

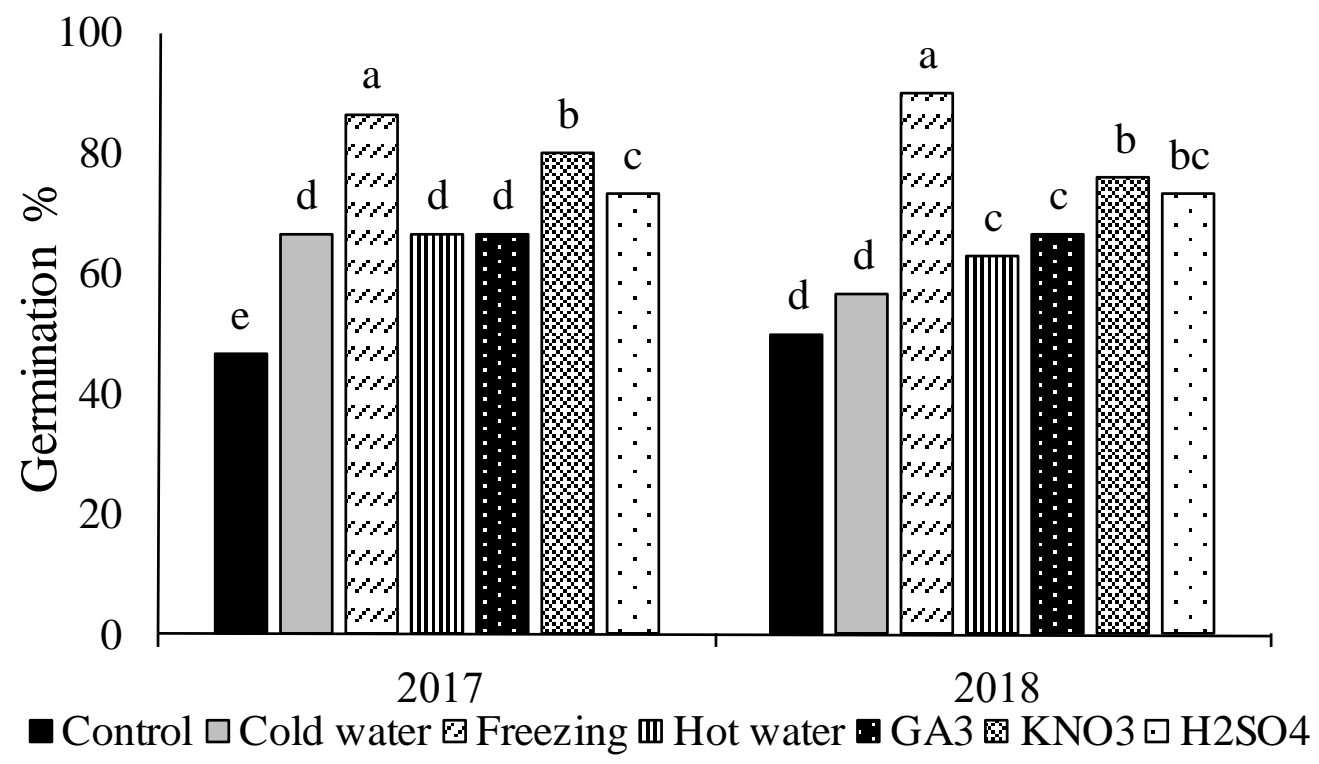

Fig. 1. Effect of various priming treatments on germination percentage of Doum palm Hyphaene thebaica seeds

\section{Root length}

Data presented in Fig. (2) showed that $\mathrm{H} 2 \mathrm{SO} 4$, gibberellic acid and cold water treatments gave significant increase in root length in both seasons when compared to other treatment. In the $1^{\text {st }}$ season $\mathrm{H} 2 \mathrm{SO} 4$, gibberellic acid and cold water gave the longest root length $(83.17,79.67$ and 79.00 $\mathrm{cm})$ and in the $2^{\text {nd }}$ season $(89.00,74.80$ and 74.47 $\mathrm{cm}$ ) in respect order. Whereas, the lowest root length was obtained when seeds were treated in the $1^{\text {st }}$ season with hot water and freezing (38.83 and $38.00 \mathrm{~cm})$ and in the $2^{\text {nd }}$ season gave (34.67, and $47.33 \mathrm{~cm}$ ) in respect order.

\section{Root diameter}

Data presented in Fig. (3) showed that cold water treatment gave significant increase in root diameter in both seasons when compared to other treatment. Whereas, the smallest root diameter was obtained when seeds were treated in the $1^{\text {st }}$ with $\mathrm{KNO}_{3}$ gave the smallest root diameter (0.6 $\mathrm{cm}$ ) and in the $2^{\text {nd }}$ season $\mathrm{H}_{2} \mathrm{SO}_{4}$ gave the smallest root diameter $(0.63 \mathrm{~cm})$. 


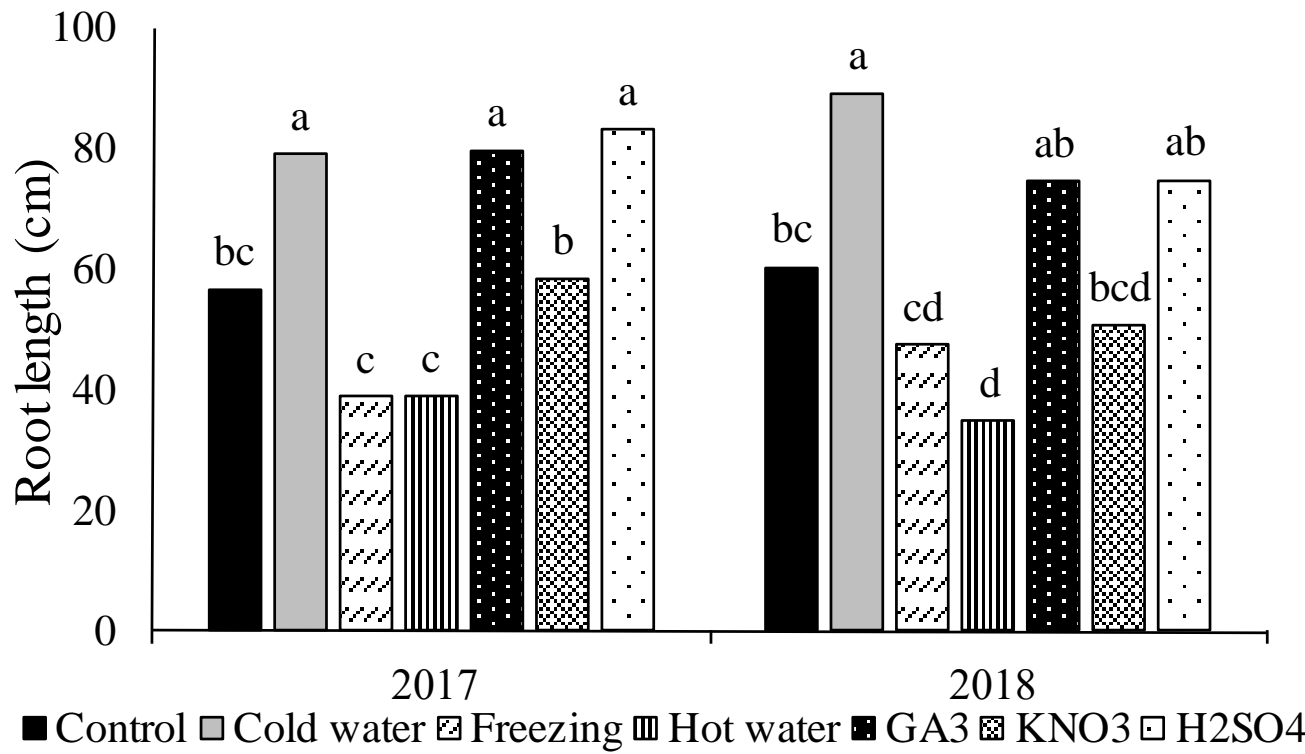

Fig. 2. Effect of various priming treatments on root length of young growing seedling of Doum palm Hyphaene thebaica

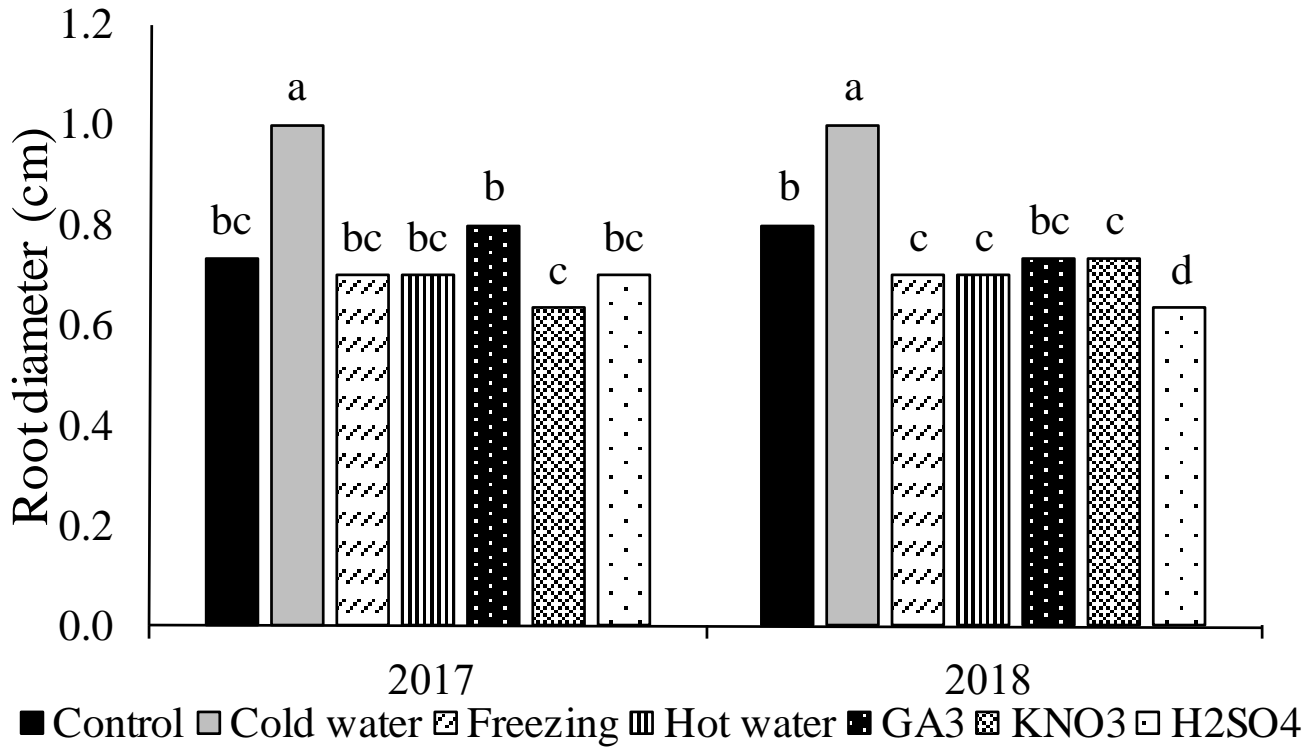

Fig. 3. Effect of various priming treatments on root diameter of young growing seedling of Doum palm Hyphaene thebaica

\section{Root fresh weight}

Data presented in Fig. (4) showed that cold water treatment gave significant increase in root fresh weight in both seasons when compared to other treatment. In the $1^{\text {st }}$ and $2^{\text {nd }}$ seasons, cold water root fresh weight was $(22.32$ and 23.02 $\mathrm{g} /$ plant) in respect order. Whereas, the lowest root fresh weight was obtained when seeds were treated in the $1^{\text {st }}$ season with hot water (10.29 g/plant) and with hot water and freezing (10.78 and 10.19 $\mathrm{g} /$ plant, respectively) in the $2^{\text {nd }}$ season. 


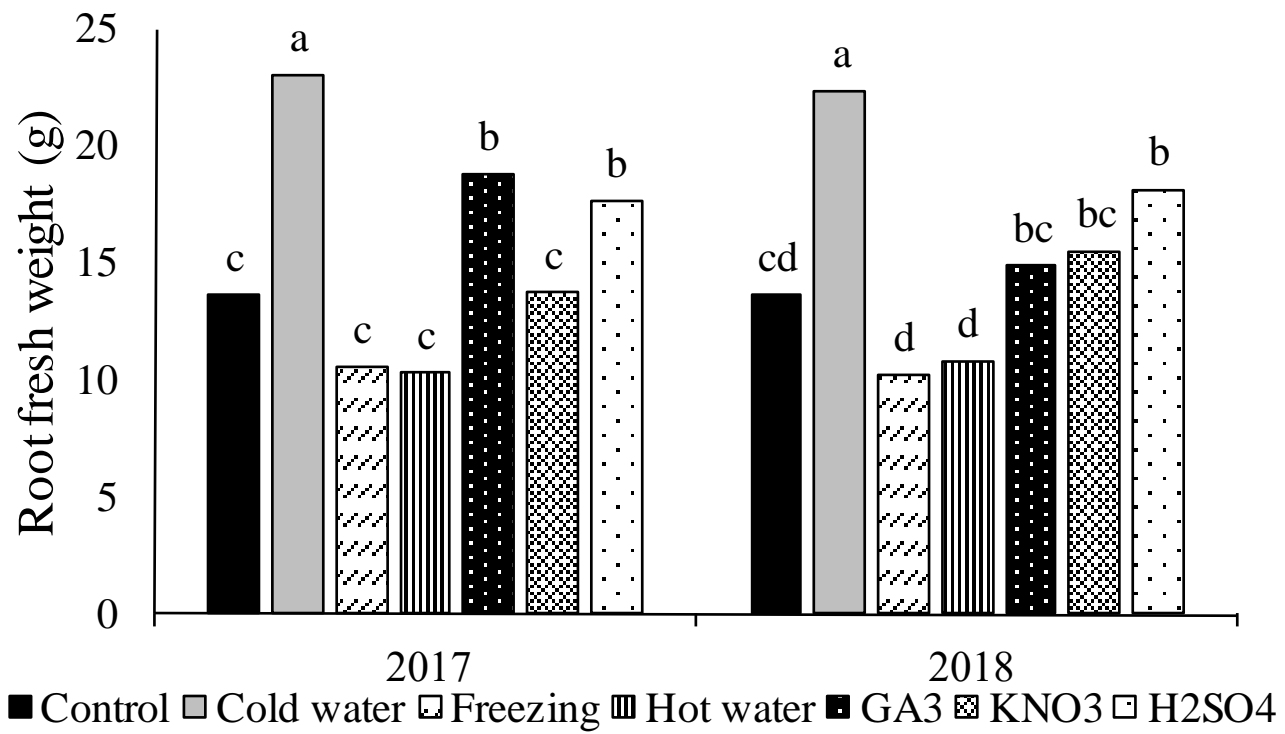

Fig. 4. Effect of various priming treatments on root fresh weight of young growing seedling of Doum palm Hyphaene thebaica

\section{Root dry weight}

Data presented in Fig. (5) indicated that cold water treatment gave significant increase in root dry weight in both seasons when compared to other treatment. Cold water treatment gave the highest value of root dry weight $(7.51$ and 7.92 $\mathrm{g} /$ plant) in respect order by seasons. Whereas, the lowest root dry weight was obtained when seeds were non-treated (control) or hot water in the $1^{\text {st }}$ season (3.97 and $3.00 \mathrm{~g} / \mathrm{plant})$ and in the $2^{\text {nd }}$ season (3.77and $3.01 \mathrm{~g} /$ plant) in respect order.

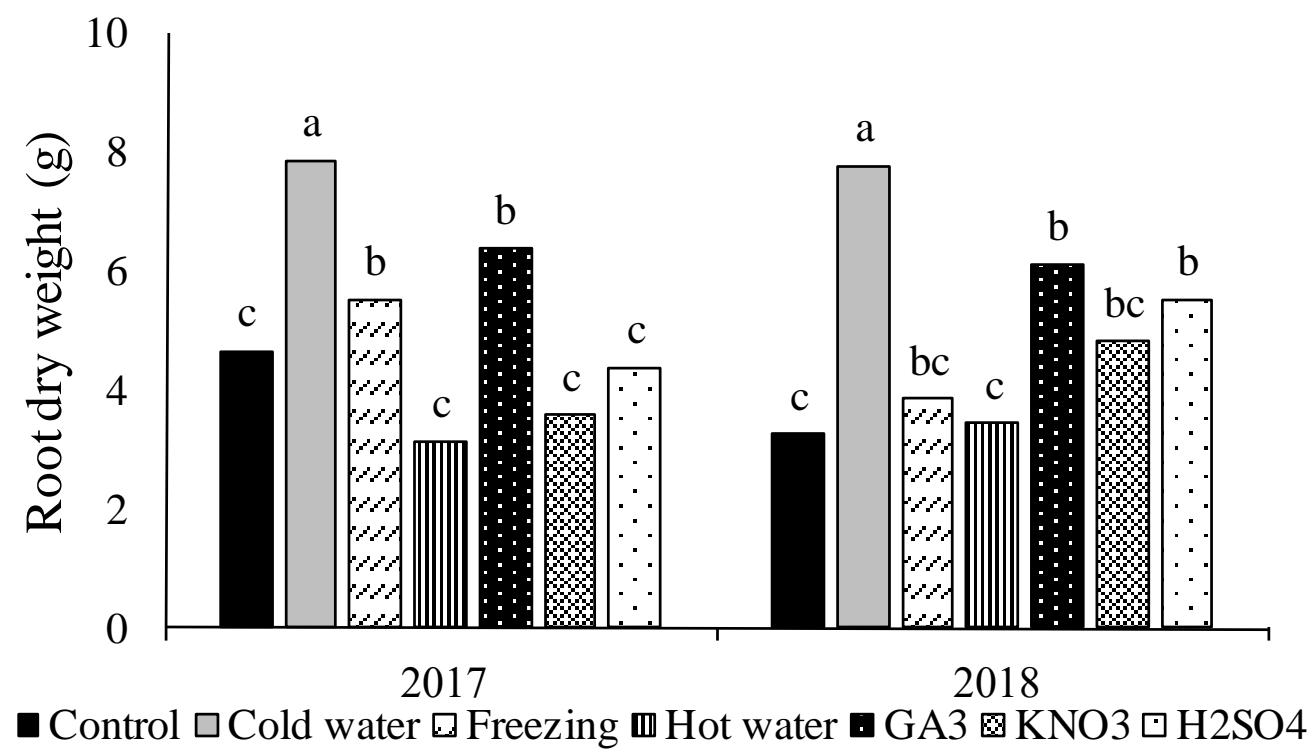

Fig. 5. Effect of various priming treatments on root dry weight of young growing seedling of Doum palm Hyphaene thebaica 


\subsubsection{Plant height}

Data presented in Fig. (6) showed that freezing, and cold water treatment gave significant increase in plant height in both seasons when compared to other treatments. In the $1^{\text {st }}$ and $2^{\text {nd }}$ seasons, freezing and cold water treatments gave significant increase in plant height in the $1^{\text {st }}$ season gave $\left(45.33\right.$ and $39.97 \mathrm{~cm}$ ) and in the $2^{\text {nd }}$ season $(44.6$ and $26.17 \mathrm{~cm})$ in respect order. Whereas, the shortest plants was obtained when seeds were treated with gibberellic acid $(28.50$ and $26.17 \mathrm{~cm})$ in respect order by season.

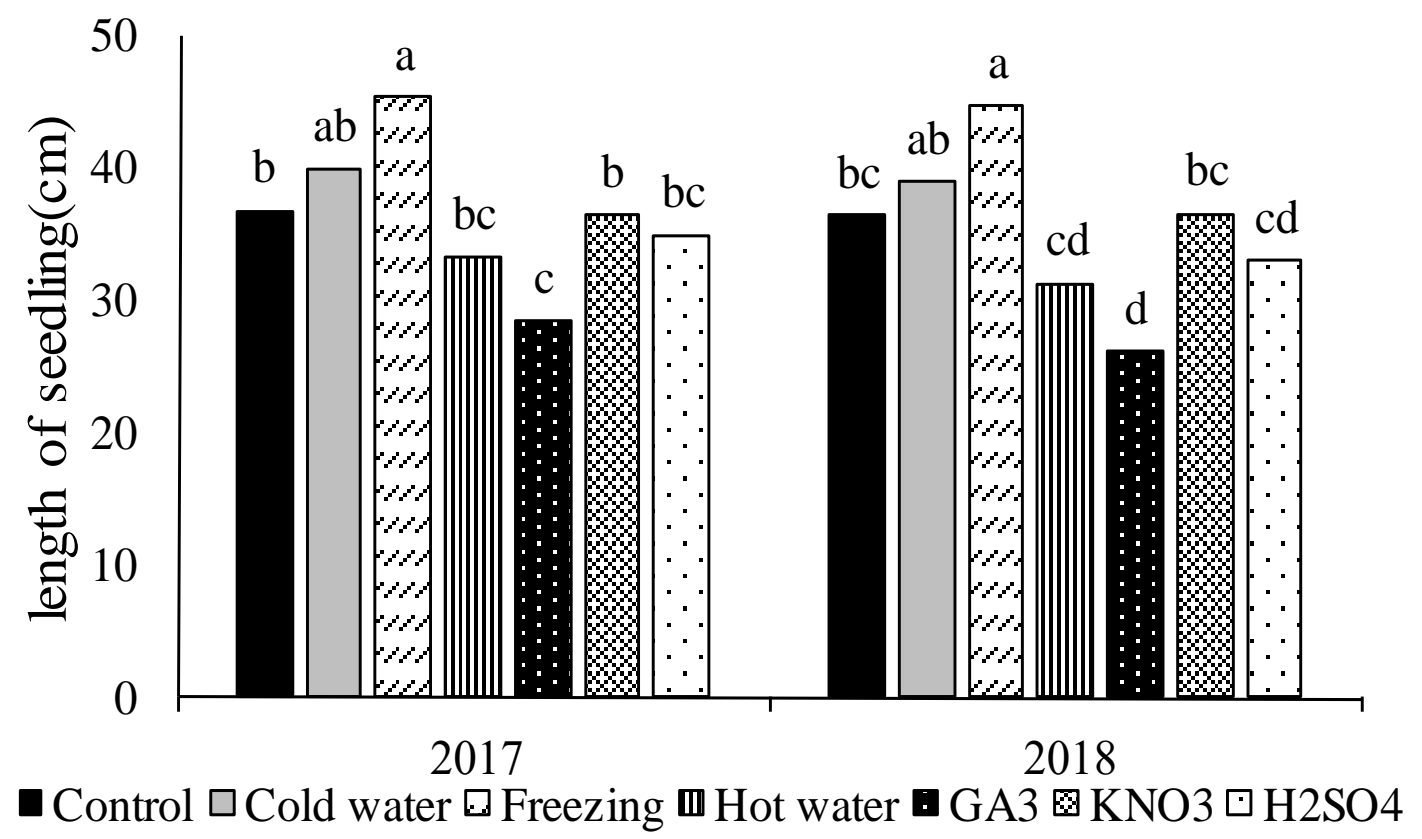

Fig. 6. Effect of various priming treatments on length of young growing seedling of Doum palm Hyphaene thebaica

\section{Leaf wide}

Data presented in Fig. (7) showed that cold water, control and $\mathrm{H}_{2} \mathrm{SO}_{4}$ treatment gave significant increase in leaf wide in both seasons when compared to other treatments. In the $1^{\text {st }}$ season cold water, control and $\mathrm{H}_{2} \mathrm{SO}_{4}$ gave larger width of leaves $(2.64,2.27$ and $2.00 \mathrm{~cm})$ and in the $2^{\text {nd }}$ season cold water and hot water gave larger width of leaves $(2.55$ and $2.50 \mathrm{~cm})$ in respect order. Whereas, the smallest leaf wide was obtained when seeds were treated with gibberellic acid $(1.52 \mathrm{~cm})$ in the $1^{\text {st }}$ and with $\mathrm{H}_{2} \mathrm{SO}_{4}$ and gibberellic acid gave the $(1.85$ and $1.70 \mathrm{~cm})$ in the $2^{\text {nd }}$ season, respectively. 


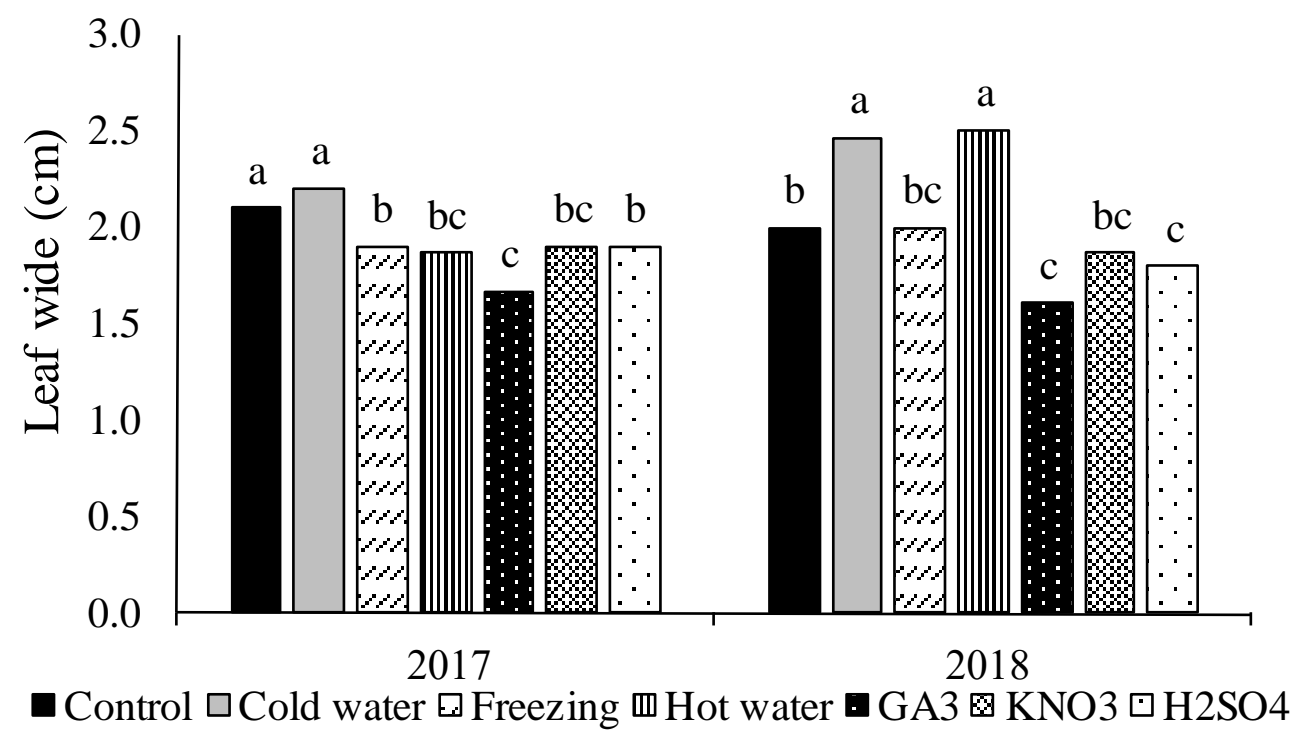

Fig. 7. Effect of various priming treatments on leaf wide of growing seedling of Doum palm Hyphaene thebaica

\section{Length of green part}

Data presented in Fig. (8) showed that freezing and $\mathrm{H}_{2} \mathrm{SO}_{4}$ treatments gave significant increase in leaf length in both seasons when compared to other treatments. In the $1^{\text {st }}$ season freezing gave the longest length of leaf $(28.03 \mathrm{~cm})$ and in the $2^{\text {nd }}$ season freezing and $\mathrm{H}_{2} \mathrm{SO}_{4}$ gave the same trend $(30.00$ and $21.67 \mathrm{~cm})$ in respect order. Whereas, the shortest of leaves were obtained when seeds were treated in the $1^{\text {st }}$ season with hot water and gibberellic acid $(13.67$ and $12.50 \mathrm{~cm})$ and in the $2^{\text {nd }}$ season gibberellic acid showed the lowest value $(12.85 \mathrm{~cm})$.

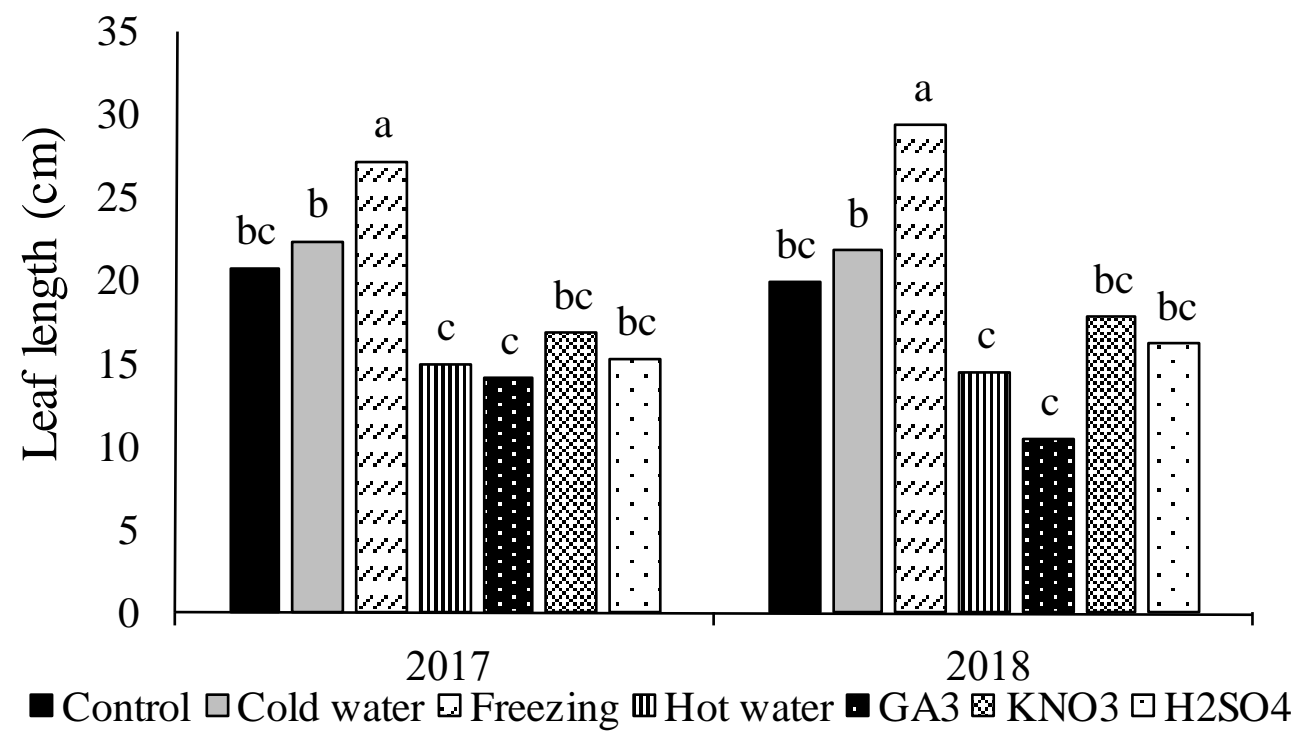

Fig. 8. Effect of various priming treatments on leaf length growing seedling of Doum palm Hyphaene thebaica 


\section{Fresh weight of aboveground part}

Data presented in Fig. (9) showed that freezing treatment gave significant increase in fresh weight of aboveground part in both seasons when compared to other treatment. Freezing gave the highest value of fresh weight for aboveground part in both seasons (14.26 and $13.09 \mathrm{~g} /$ plant) in respect order. Whereas, the lowest aboveground part fresh weight was obtained when seeds were treated in the $1^{\text {st }}$ with hot water, $\mathrm{KNO}_{3}$ and gibberellic acid (6.56, 6.25 and $5.56 \mathrm{~g} /$ plant) and in the $2^{\text {nd }}$ season gibberellic acid gave (3.92 g/plant).

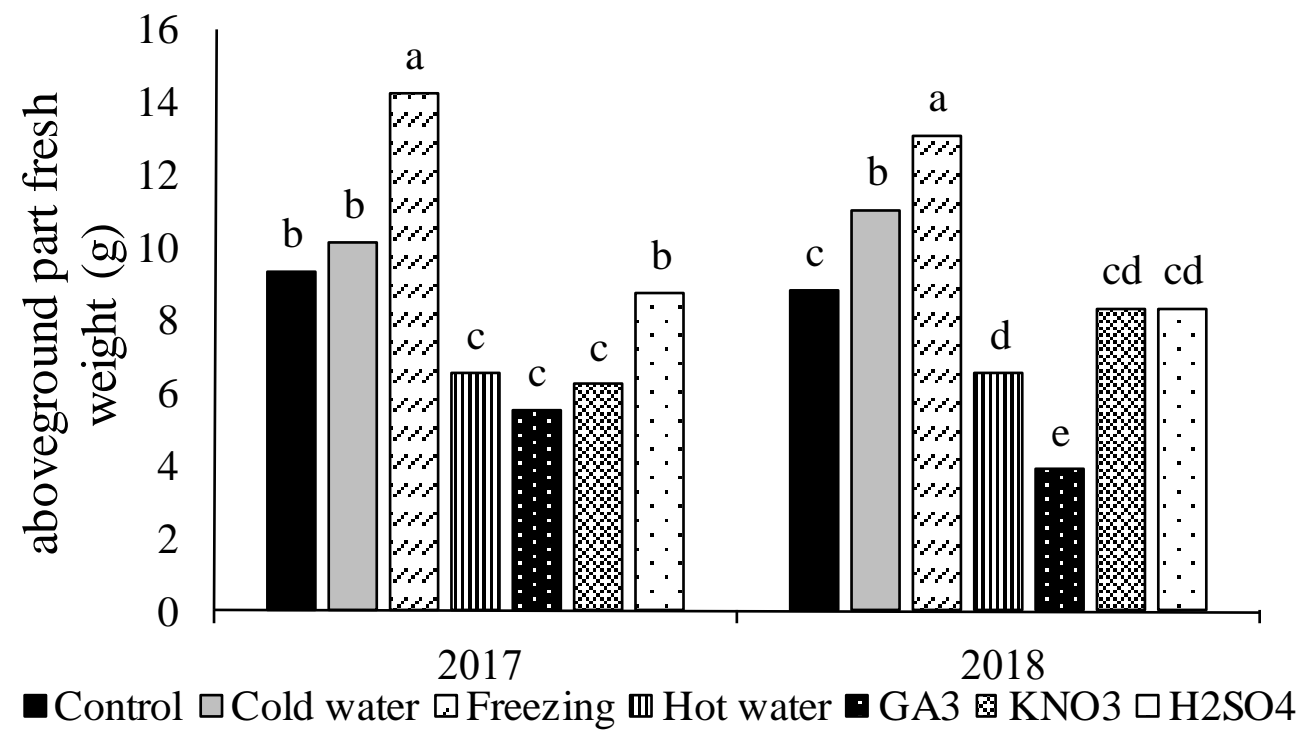

Fig. 9. Effect of various priming treatments on aboveground fresh weight of growing seedling of Doum palm Hyphaene thebaica

\section{DISCUSSION}

Pre-germination treatments were carried out to investigate the effect of different seed treatments on germination percentage and growth rate of young seedling of Doum palm Hyphaene thebaica Mart.

Results obtained here, showed that the highest percentages of seed germination of $H$. thebaica Mart were obtained when seeds were treated with freezing storage in deep-freezer at $-18^{\circ} \mathrm{C}$ for 12 hours then soaked in hot water at $60^{\circ} \mathrm{C}$ for 1 hour. These findings are in agreement with those reviewed on effect of freeze-thaw scarification that breaks the seed coat by exposing seeds to temperature alternations between low and high (Stout, 1990; Rutar et al 2001). None of the previously studied research on seed priming of Doum palm tried the effect of freeze. Idohou et al (2015) on Doum $H$. thebaica Mart seeds reported that, the time of germination and water soaking had significant effects on seed germination. Also, Al-fredan and Ali (2008) reported thet on Doum palm seeds gave the highest seed germination percentage $(93 \%)$ when seeds were mechanically scarificated then soaked in water for $24 \mathrm{~h}$. Non treated seeds gave the lowest germination percentage as well as hot water and treated seeds with gibberellic acid followed by $\mathrm{H}_{2} \mathrm{SO}_{4}$. The sulpharic acid treated seeds resulted in a low germination percentage (32\%). Tahir et al (2007) on $H$. thebaica Mart. Çırak et al (2007) on Hypericum aviculaviifolium. Also, Kasera et al (2002) found that Leptadaenia reticulate seeds subjected to soak in water for $24 \mathrm{~h}$ gave the highest seed germination percentage 100\%. Sreerama et al (2000) on Cassia fistula, C. spectabilis and Delonix regia seeds, Moussa et al (1998) on Doum palm Hyphaene thebaica Mart seeds.

These above results may be explained by the fact that seed scarification might have removed the mechanical resistance of seed coat and this enabled the embryo to germinate without any mechanical obstacle. 

and development of small seedling

Mechanism behind the reduction of seed hardness by a freeze-thaw scarification is to make tiny scars on hard seed coat and make seed coat brittle to enhance germination (Busse, 1930; Stout, 1990; Hall et al 1993). A force that produces scars on seed surface through this technique is depending on the size, shape and water content of seeds and treatment intensity and durations (Kimura and Islam, 2012). Methods for cooling in freeze-thaw scarification include freezer, (Shibata and Hatakeyama, 1995); carbon dioxide $\left(\mathrm{CO}_{2}\right)$ snow, dry ice, liquid air (Busse, 1930); ultra-low freezer (Stout, 1990); acetone (Rutar et al 2001); liquid N (Patane and Gresta, 2006). These findings are in agreement with those reviewed by Witte (1977) on Zamia integri-folia. The result of freezing on young growing seedling showed similar trend to cold water treatment. Also, similar results in agree on importance of lower temperature on seed germination Tilki and Dirik (2007) on pinus brutia, Millaku et al (2012) on Gentiana lutea L. and Kolotelo et al (2001) on some Conifer species.

Cracker and Barton (1953) concluded that low vigor seeds may need more water to germinate than high vigor seeds, and Hegarty (1978) contended that loss of vigor precedes loss of viability. Whereas, Martinková and Honěk, (2007) on Taraxacum officinale as the manner of seed storage has no effect on percentage of germination, frozen seed may be used safely for experiments studying this quality of seed materials. Thus, of lower germination \% resulted from non-treated or cold water seeds, did not negative their effect for better growing young seedling.

Priming methods such as heat, freeze, mechanical and acid scarification are useful tools to soften hard seeds, improve germination and enhance seedling establishment. However, effectiveness of the methods varies depending on the duration of imposed treatments and species or cultivars to be used (Taia, 2004). Over treatment or longer time scarification may impose negative impacts on or injury to the seeds.

\section{REFERENCES}

Al-Fredan M.A. and Ali Y.S. 2008. Seed Scarification Requirement in Doum (Hyphaene thebaica Mart.). Scientific J. of King Faisal Univ. (Basic and Applied Sci.), 9(2), 14-29.

Busse W.F. 1930. Effect of low temperatures on germination of impermeable seeds. Bot. Gazette, 89, 169-179.
Cervantes V., Carabias J. and Vázquez-Yanes C. 1996. Seed germination of woody legumes from deciduous tropical forest of southern Mexico. Forest Ecology and Management, 82(13), 171-184.

Chris M. 1994. Presowing seed treatments on four African Acacia species: appropriate technology for use in forestry for rural development. Forest Ecology and Management, 64(I. 2-3), 105109.

Çırak C., Kevseroğlu K. and Ayan A.K. 2007. Breaking of seed dormancy in a Turkish endemic Hypericum species: Hypericum aviculariifolium subsp. depilatum var. depilatum by light and some pre-soaking treatments. J. of Arid Environments, 68(1), 159-164.

Cracker W. and Barton L.V. 1953. Physiology of seeds. Cronica Botanica Co., Waltham, Mass. 75(5), 406.

Garner J.L. and Lewis A.J. 1980. An evaluation of techniques used for germinating goldenrain tree seeds. American Nurseryman, 151(8), 12-36.

Gogue G.J. and Emino E.R. 1979. Seed coat scarification of albizia-julibrissin durazz by natural mechanisms. J. of the American Society for Horticultural Sci., 104(3), 421-423.

Gupta V., Anjali K. and Singh B.B. 2001. Techniques to remove hard seeded ness in the wild medicinal plant Abutilon indicum. J. Medicinal and Aromatic PI. Sci., 23(2), 369-371.

Hall J.W., Stout D.G. and Brooke B.M. 1993. Hard seed and field establishment of irrigated Alfalfa. Crop Sci., 33, 1025-1028.

Hegarty T.W. 1978. The physiology of seed hydration and dehydration, and the relation between water stress and the control of germination: a review. Plant, Cell, Environ. 1, 101-119.

Idohou R., Assogbadjo A.E., Houehanou T., Kakaï R.G. and Agbangla C. 2015. Variation in Hyphaene thebaica Mart. fruit: physical characteristics and factors affecting seed germination and seedling growth in Benin (West Africa). The J. of Horticultural Sci. and Biotechnology, 90(3), 291-296.

Kasera P.K., Shukla J.K. and Chawan D.D. 2002. Gerrmination, Ecophysiology and agrotechniqus studies on Leptadaenia reticulate- An endangered species of medicinal value from arid zone. J. of Medicinal and Aromatic Plant Sci., 24(4), 972-977.

Kimura E. and Islam M.A. 2012. Seed scarification methods and their use in forage legumes. Research J. of Seed Sci., 5(2), 38-50. 
Kolotelo D., Steenis E.V., Bennett M., Trotter D. and Dennis Y.J. 2001. Seed Handling Guidebook. Ministry of Forests, Tree Improvement Branch. British Columbia, Canada, 106 p.

Martinková Z. and Honěk A. 2007. The effect of cryopreservation on germination of dandelion seeds. Plant Protection Sci.,-UZPI (Czech Republic), 43(2), 63-67.

Millaku F., Gasshi B., Abdullai K., Aliu S., Osmani M., Krasniqi E., Mata V. and Rysha A. 2012. Effects of cold-stratification, gibberellic acid and potassium nitrate on seed germination of yellow gentian (Gentiana lutea L.). African J. of Biotechnology, 11(68), 13173-13178.

Moussa H., Margolis H.A., Dubé P.A. and Odongo J. 1998. Factors affecting the germination of doum palm (Hyphaene thebaica Mart.) seeds from the semi-arid zone of Niger, West Africa. Forest Ecology and Management, 104(1-3), 27-41.

Patane C. and Gresta F. 2006. Germination of Astragalus hamosus and Medicago orbicularis as affected by seed-coat dormancy breaking techniques. J. Arid Environ., 67, 165-173.

Rutar R., Stjepanovic M., Popovic S., Bukvic Z. and Pacek D. 2001. Effect of temperature on germination and hard alfalfa seed. CIHEAM, 2, 137-139.

Shibata, T. and Hatakeyama, Y. 1995. Breaking of dormancy in the seeds of Astragalus mongholicus Bunge (Leguminosae). J. Plant Physiol., 146, 366-368.

Smith G.S. 1978. Seed scarification to speed germination of ornamental cycads (Zamia spp.). HortScience., 13, 436-438.
Snedecor G.W. and Cochran W.G. 1989. Statistical methods 8th edition, lowa State Univ., Press, Amed, lowa, USA. pp. 297-329.

Sreerama R., Krishnappa N., Reddy T.V. and Reddy M.A.N. 2000. Effect of pre-sowing treatments on seed germination of ornamental trees. Current Research-Univ. of Agric. Sci. (Bangalore), 29(7/8), 127-128.

Stout D.G. 1990. Effect of freeze-thaw cycles on hard-seededness of alfalfa. J. Seed Technol., 14, 47-55.

Tahir S.M., Mu'azu S., Khan A.U. and lortsuun D.N. 2007. Studies on the germination and seedling characteristics of the savanna palm trees. Sci. World J., 2(3), 25-31.

Taia W.K. 2004. Tribe Trifolieae: Evidence from seed characters. Pak. J. Biol. Sci., 7, 1287-1302.

Tilki F. and Dirik H. 2007. Seed germination of three provenances of Pinus brutia (Ten.) as influenced by stratification, temperature and water stress. J. of Environmental Biology, 28(1), 133-136.

Waller R.A. and Duncan D.B. 1969. A Bayes rule for the symmetric multiple comparisons problem. J. Am. Stat. Assoc. 46, 1484-1503.

Witte W.T. 1977. Storage and germination of Zamia seed (Propagtion). In Proceedings of the Florida state horticultural Society. 90, 89-91.

Zevallos P.P. and De La Cruz S.H. 1991. Tratamientos pregerminativos y repique de regeneración natural en vivero con cinco especies forestales de Cajamarca. Revista Forestal del Perú Lima, Perú. 18(1), 39-46. 


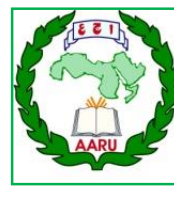

مجلة اتحاد الجامعات العربية للعلوم الزراعية، جامعة عين شمس، القاهرة، مصر مجلا(27)، عدد(4)، 2257-2247، 2019

Website: http://ajs.journals.ekb.eg

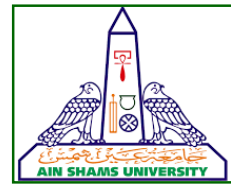

2257

تأثير معاملات البذور علي إنبات بذور نخيل الدوم (Hyphaene thebaica Mart)

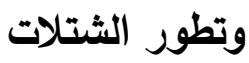

[179]

\author{
أحمد حسني عبدالحي نجم"1 - سهير السيد حسن2 2 \\ 1- معهد الدراسات والبحوث الزراعية في الأراضي القاحلة - جامعة عين شمس - القاهرة - مصر

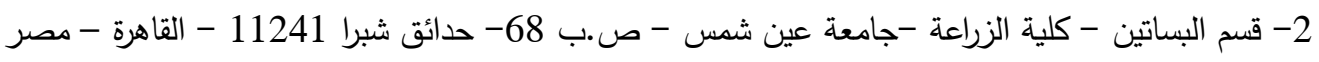

${ }^{*}$ Corresponding author: negm.a.h@agr.asu.edu.eg

Received 29 August, 2019 Accepted 12 November, 2019

بتركيز 200 جزء في المليون لمدة 48 ساعة، حامض لأ الكبريتيك بتركيز 30\% لمدة 15 دقيقة فيقة، التجميد علي 18\% م. أظهرت معاملة التجميد أعلي نسبة إنبات

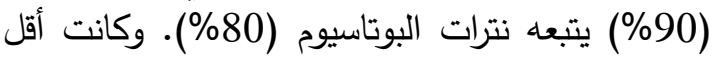
نسبة إنبات كانت من المقارنة والماء البأرد بـاء بنسبة (45-45\%). وكان لمعاملة التجميد والماء البارد تأثير

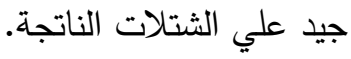

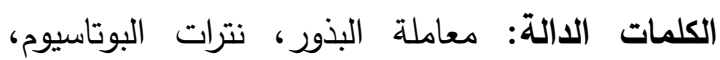

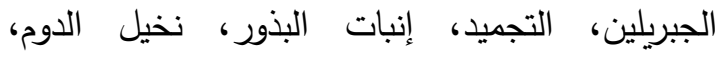

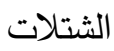<smiles>[AlH2][AlH2]</smiles>

نخيل الدوم يعتبر من أهم نبات الفلورا المصرية. تدخل ثمار الدوم في العديد من المنتجات التهات الغذائية

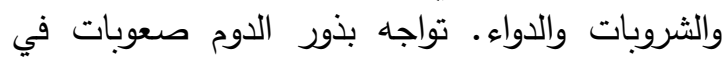

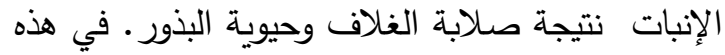

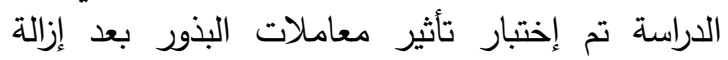

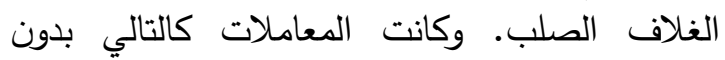

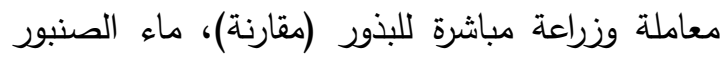
(ماء بارد)، المعاملة بالماء الساخن لمدة 3 ساعات

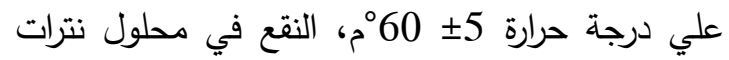
البوتاسيوم 3\% لمدة 48 ساعة، حامض الجبريليك 